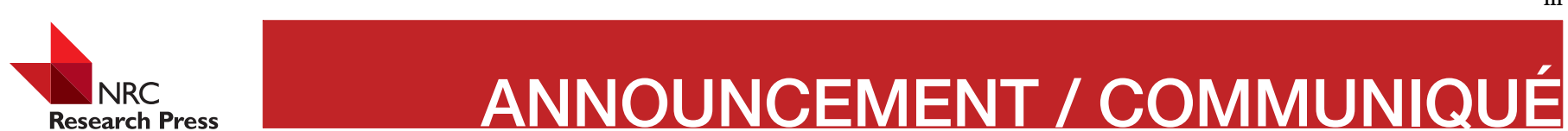

\section{Appointment of a new Deputy Executive Editor-in-Chief}

On behalf of the Board of Directors, journal Editors, and staff of Canadian Science Publishing, I am pleased to announce that M. Brock Fenton has agreed to serve as the Deputy Executive Editor-in-Chief for a three-year term effective November 1, 2018.

As the former Co-Editor of the Canadian Journal of Zoology from 2003 to 2015 and a current subject editor for FACETS, Brock has long been a dedicated supporter of Canadian Science Publishing and its journals.

In his capacity as Deputy Executive Editor-in-Chief, Brock will

- $\quad$ support the Executive Editor-in-Chief in his duties by providing advice, recommending or assessing potential editorial appointments, contributing to the strategic development of the journals, and representing the Executive Editor-in-Chief at events as needed;

- uphold the ethics and values associated with scholarly publishing;

- $\quad$ promote Canadian Science Publishing, working to develop and maintain its high-quality reputation;

- lead various special projects and activities that support the above responsibilities or that contribute to the advancement of Canadian Science Publishing's strategic goals or to the scholarly community in general.

Brock received his Ph.D. in 1969 for work on the ecology and behaviour of bats. He has held academic positions at Carleton University, York University, and The University of Western Ontario. Brock has published over 250 papers in refereed journals and has written four books about bats. He continues his research on bats, with a special emphasis on echolocation and evolution. He currently is an Emeritus Professor of Biology at The University of Western Ontario in London, Canada. He was inducted as a Fellow of the Royal Society of Canada in November 2014.

Please join me in welcoming Brock Fenton to his new position.

\section{Jim Germida}

Executive Editor-in-Chief

\section{Nomination d'un nouveau directeur adjoint de la publication}

Au nom du conseil d'administration, des rédacteurs en chef de la revue et du personnel de Canadian Science Publishing, je suis heureux d'annoncer que M. Brock Fenton a accepté le poste de directeur adjoint de la publication pour un mandat d'une durée de trois ans. Il entrera en fonction le $1^{\mathrm{er}}$ novembre prochain.

À titre d'ancien corédacteur en chef du Canadian Journal of Zoology de 2003 à 2015 et d'actuel rédacteur pour FACETS, Brock est un contributeur de longue date des Canadian Science Publishing et de ses revues.

Dans le cadre de son rôle de directeur adjoint de la publication, Brock :

- appuiera le directeur de la publication dans ses fonctions en lui donnant des conseils, en lui recommandant ou en évaluant des candidats potentiels à des postes éditoriaux, en contribuant au développement stratégique des revues, et en représentant le directeur de la publication lors d'événements, au besoin;

- respectera l'éthique et les valeurs associées à l'édition scientifique;

- assurera la promotion des Canadian Science Publishing et veillera à développer et maintenir sa réputation d'excellence;

- dirigera un éventail de projets spéciaux et d'activités liés aux responsabilités indiquées cidessus ou qui contribuent à l'atteinte des objectifs stratégiques des Canadian Science Publishing ou de l'ensemble de la communauté scientifique.

Brock a obtenu son doctorat en 1969 pour ses travaux portant sur l'écologie et les comportements des chauves-souris. Brock a occupé des postes universitaires à la Carleton University, à l'Université York et à la University of Western Ontario. Il a publié plus de 250 articles dans des revues spécialisées et écrit quatre ouvrages sur les chauves-souris. Il poursuit ses recherches sur les chauvessouris, en se penchant notamment sur leur capacité d'écholocalisation et l'évolution de l'espèce. Il est actuellement professeur émérite de biologie à la University of Western Ontario à London, au Canada. Il a été intronisé membre de la Société royale du Canada en novembre 2014.

Veuillez vous joindre à moi pour souhaiter la bienvenue à Brock Fenton dans ses nouvelles fonctions.

Jim Germida

Directeur de la publication 